\title{
Fungsi Sistolik dan Diastolik Ventrikel Kiri pada Anak dengan Leukemia Limfoblastik Akut Pasca Terapi Daunorubisin
}

\author{
Mahrus A Rahman
}

Latar belakang. Pengobatan utama limfomia limfoblastik akut (LLA) adalah kemoterapi. Sitostatik yang paling sering memberikan efek samping pada sistem kardiovaskuler adalah golongan antrasiklin yaitu doksorubisin dan daunorubisin. Tanda awal kardiomiopati karena antrasiklin adalah gangguan fungsi diastolik. Adanya gangguan fungsi ventrikel dapat dibuktikan dengan metode radionuklid dan ekokardiografi Doppler.

Tujuan penelitian. Memperoleh data fungsi diastolik dan sistolik ventrikel kiri, dimensi ventrikel kiri, dan status gizi pada anak dengan LLA pasca terapi daunorubisin.

Metode. Penelitian cross sectional meneliti fungsi diastolik dan sistolik ventrikel kiri pada 19 anak LLA pasca terapi daunorubisin. Sebagai kontrol penelitian 21 anak LLA tanpa terapi daunorubisin dan 18 anak sehat. Pemeriksaan fungsi dan dimensi ventrikel kiri dilakukan dengan pemeriksaan ekokardiografi 2D, M mode dan Doppler. Analisis statistik hasil penelitian dilakukan dengan mempergunakan uji ANOVA dan Chi-square. Hasil. Terdapat 12 dari 19 anak pada kelompok studi dan 5 dari 21 anak pada kelompok kontrol LLA yang mengalami gangguan fungsi diastolik ventrikel kiri dengan pola penurunan relaksasi. Pola penurunan relaksasi terdapat pada kardiomiopati hipertrofi maupun kardiomiopati dilatasi, hipertrofi ventrikel kiri karena berbagai sebab, penyakit jantung iskemik, preload yang menurun, dan afterload yang meningkat. Pada kelompok kontrol LLA juga sudah terdapat gangguan fungsi diastolik ventrikel kiri. Disamping daunorubisin terdapat faktor lain yang mempengaruhi fungsi diastolik ventrikel kiri, penyakitnya sendiri dan obat-obat lain. Gangguan fungsi sistolik ventrikel kiri hanya didapatkan pada 1 anak kelompok studi. Hal ini disebabkan oleh dosis kumulatif daunorubisin yang masih relatif rendah dan follow up yang masih pendek. Tidak terdapat perubahan dimensi ventrikel kiri pada kelompok studi dibandingkan kelompok kontrol; belum terjadi kardiomiopati yang berhubungan dengan dosis kumulatif yang tinggi dan penggunaan yang lama untuk timbulnya manifestasi klinis. Pada kelompok studi tidak didapatkan perbedaan yang bermakna antara gizi dengan timbulnya gangguan fungsi diastolik.

Kesimpulan. Pada anak dengan penyakit leukemia limfoblastik akut pasca terapi daunorubisin dosis kumulatif $120 \mathrm{mg} / \mathrm{m} 2$ telah mengalami gangguan fungsi diastolik ventrikel kiri, sedangkan fungsi sistolik tidak terganggu. Dimensi ventrikel kiri tidak mengalami perubahan. Tidak terdapat perbedaan status gizi pada anak dengan fungsi diastolik ventrikel kiri terganggu.

Kata kunci: leukemia limfoblastik, fungsi sistolik dan diastolik, ventrikel kiri, daunorubisin

Alamat korespondensi:

Dr. Mahrus A Rahman,SpA(K). Divisi Kardiologi Lab / SMF. Bagian Ilmu Kesehatan Anak FK-

TDC UNAIR RS Dr. Soetomo. J1 Prof. Dr. Moestopo 6-8. Surabaya, 60132. 40061/3916. 
p Penyakit keganasan pada anak semakin lama semakin meningkat, membawa masalah bagi pasien maupun keluarganya. ${ }^{1}$ Penyakit leukemia limfoblastik akut (LLA) merupakan penyakit keganasan paling banyak dijumpai, merupakan sepertiga dari seluruh penyakit keganasan pada anak. Insidens hampir sama di seluruh dunia, 30 kasus per 1 juta penduduk puncaknya pada usia 2-5 tahun. Perjalanan penyakit LLA dikelompokkan dalam risiko tinggi dan risiko biasa berdasarkan gambaran klinis umum dan hitung lekosit. Termasuk dalam kelompok risiko biasa apabila umur 1-10 tahun, hitung leukosit $<50.000$. Kelompok risiko tinggi apabila di luar kriteria risiko biasa. Four y EFS (four year event free survival) pada risiko biasa $80 \%$, pada risiko tinggi $65 \%$.

Pengobatan LLA yang utama adalah kemoterapi karena penyakit ini adalah penyakit sistemik. Tujuan pengobatan adalah mematikan sel patologis sedangkan sel normal diusahakan sesedikit mungkin terpengaruh. ${ }^{2}$ Pada pengobatan tersebut tidak dapat dihindari timbulnya efek samping dari yang paling ringan sampai yang paling berat, menyerang berbagai organ tubuh. Efek samping pada organ dapat terlihat pada depresi sumsum tulang, gangguan saluran cerna, hati, kardiovaskular, susunan saraf pusat, paru, saluran kemih, gonad, kulit, rambut. Efek samping tersebut dapat membahayakan dan mengganggu kualitas hidup pasien. ${ }^{3}$

Sitostatik yang paling sering memberikan efek samping pada sistem kardiovaskular adalah golongan antrasiklin yaitu doksorubisin dan daunorubisin. Efek samping yang timbul berupa kardiomiopati dengan manifestasi gagal jantung kongestif dan aritmia. Angka kejadian gagal jantung kongestif akibat antrasiklin ini sekitar 2,2\%, dan mempunyai prognosis yang jelek. ${ }^{4}$ Tanda awal kardiomiopati karena antrasiklin adalah gangguan fungsi diastolik. ${ }^{5,6}$ Adanya gangguan fungsi diastolik ventrikel kiri tanpa gangguan fungsi sistolik pada pasien dewasa dan anak pasca terapi antrasiklin jangka panjang dibuktikan dengan metode radionuklid dan ekokardiografi dopler. ${ }^{5,78}$ Cottin Y dkk ${ }^{9}$ dengan metode radionuklid menemukan adanya gangguan fungsi sistolik dan diastolik ventrikel kiri yang simultan pada pasien dewasa 1 bulan pasca terapi antrasiklin.

Sampai sekarang belum ada data di Lab/ SMF Ilmu Kesehatan Anak RSU Dr. Soetomo tentang gambaran fungsi ventrikel setelah terapi dengan daunorubisin pada LLA. Tujuan penelitian ini adalah memperoleh data fungsi diastolik dan sistolik ventrikel kiri, dimensi ventrikel kiri, dan status gizi pada anak dengan LLA pasca terapi daunorubisin.

\section{Metoda}

Penelitian belah lintang (studi cross sectional) pada pemeriksaan fungsi ventrikel dengan ekokardiografi Mmode dan Doppler untuk menentukan perubahan fungsi dan dimensi ventrikel kiri, serta perbedaan status gizi pada anak dengan LLA pasca terapi daunorubisin. Penelitian dilakukan di divisi Kardiologi dan divisi Hematologi, Bagian Ilmu Kesehatan Anak RSU Dr Soetomo Surabaya, 1 Nopember - 31 Desember 2004. Sampel penelitian adalah anak dengan LLA pasca terapi daunorubisin, diambil secara konsekutif yang memenuhi kriteria penelitian. Pasien kontrol adalah anak dengan LLA tanpa terapi daunorubisin dan anak sehat. Besar sampel untuk kelompok studi 19 orang, kelompok kontrol LLA 21 orang dan kelompok kontrol sehat 18 orang. Pasien dikeluarkan dari penelitian apabila menderita penyakit jantung bawaan, penyakit jantung rematik / penyakit jantung didapat lainnya, aritmia, hipertensi, infeksi berat, sepsis, bronkopneumonia, dan anemia berat $(\mathrm{Hb}<10 \mathrm{~g} / \mathrm{dl})$. Terhadap pasien yang memenuhi kriteria penelitian dilakukan pencatatan identitas, pengukuran berat badan, tinggi badan, luas permukaan tubuh, status gizi, diagnosis penyakit, jenis kemoterapi yang didapat, dosis kumulatif daunorubisin /m2. Lama pemantauan dihitung dari tanggal pemberian daunorubisin dosis terakhir dan tanggal pemeriksaan ekokardiografi terakhir.

Anamnesis adanya gejala gagal jantung kongestif yaitu keluhan sesak napas, cepat lelah, bengkak di kaki/ badan, pemeriksaan fisis lengkap,dan pemeriksaan ekokardiografi. Seluruh pemeriksaan ekokardiografi 2 dimensi, M-mode dan Doppler dilakukan oleh peneliti, pasien tidur terlentang dalam keadaan tenang tanpa sedasi dengan metode standar. Pemeriksaan dilakukan dengan mesin Logic-400, transduser frekuensi 2,5 MHz model 2121793-2. Ekokardiografi 2D dilakukan untuk menyingkirkan kelainan anatomis. Pemeriksaan M-mode dilakukan pada anak dengan posisi tidur terlentang, dan secara simultan dilengkapi tayangan elektrokardiografi. Rekaman dilakukan pada kecepatan 50-100 mm/detik. Dicatat dimensi ventrikel kiri saat sistolik dan diastolik, 
ketebalan septum ventrikel dan dinding belakang ventrikel kiri saat sistolik dan diastolik. Pemeriksaan fungsi sistolik ventrikel kiri, fraksi ejeksi (FE) dan fraksi pemendekan (FP) dengan metode standar. Semua pemeriksaan pada saat ekspirasi maksimal, mengukur nilai-nilai tersebut pada 3 siklus respirasi berbeda kemudian dihitung nilai reratanya. Pengisian diastolik ventrikel diukur dengan menempatkan sampel volum diantara ujung daun katup mitral pada pandangan apikal 4 ruang. Kesejajaran gelombang ultrasonik dengan arus darah diatur dengan manipulasi transduser sampai diperoleh kecepatan spektral yang tertinggi dan suara yang jernih. Kecepatan modal (m/detik) gelombang $\mathrm{E}$ dan $\mathrm{A}$ serta rasio E/A diukur secara elektronik. Pengukuran dilakukan saat ekspirasi maksimal pada 3 siklus yang berbeda, kemudian dicatat nilai reratanya.

Fungsi diastolik ventrikel kiri yang diukur adalah: Puncak E dan puncak A (m/detik), Rasio E/A. Nilai normal $^{57}: \mathrm{E}=0,97 \pm 13 \mathrm{~m} / \mathrm{dt}$ (umur $>1$ th), $\mathrm{A}=0,54 \pm$ $14 \mathrm{~m} / \mathrm{dt}, \mathrm{E} / \mathrm{A}=1,7 \pm 0,4-2,5 \pm 0,9$ Fungsi diastolik dikatakan terganggu apabila nilai E,A atau rasio E/A diluar nilai normal. Fungsi sistolik ventrikel kiri yang diukur adalah fraksi ejeksi $=\mathrm{FE}(\%)$ dan fraksi pemendekan $=$ FP. Nilai normal ${ }^{57}: \mathrm{FE}=64-83 \% \mathrm{FP}=$ $28-44 \%$. Fungsi sistolik Vki terganggu apabila nilai FE atau FS diluar nilai normal. Nilai normal dimensi ventrikel kiri sesuai tabel dalam Pediatric Cardiology for Practitioner. ${ }^{10}$ Status gizi ditentukan dengan standard NCHS menurut umur dan berat badan.

Pengolahan data menggunakan program komputer SPSS. Data disajikan dalam bentuk tekstular dan tabel. Untuk menentukan adanya gangguan fungsi diastolik dan sistolik ventrikel, dan adanya perubahan dimensi ventrikel kiri, dilakukan uji ANOVA (data numerik).Untuk menentukan pengaruh status gizi terhadap gangguan fungsi diastolik dan sistolik ventrikel, dan perubahan dimensi ventrikel kiri dilakukan uji Chisquare (data nominal). Pada analisis statistik disertakan jenis uji, nilai p, atau interval kepercayaan 95\%. Nilai kemaknaan adalah $\mathrm{p}<0.05$, uji 2-arah.

\section{Hasil}

Terdapat 72 anak dengan LLA yang terdaftar di poliklinik Hematologi Anak Lab/SMF Ilmu Kesehatan Anak RSU Dr Soetomo Surabaya. Protokol pengobatan LLA yang dipakai adalah protokol ALL Wijaya
Kusuma 2000 (WK-ALL-2000). Pasien LLA risiko tinggi mendapat terapi methotrexate, vincristine, dexamethason, L-asparaginase, daunorubisin, dan 6mercaptopurin, terdiri dari fase induksi, konsolidadi, reinduksi dan lanjutan. Pada LLA risiko standar mendapat terapi methotrexate, vincristine, dexamethason, L-asparaginase, dan 6-mercaptopurin. Terapi terdiri dari fase induksi, konsolidasi dan lanjutan. Terdapat 29 anak yang mendapat regimen terapi risiko tinggi dan 43 anak dengan regimen terapi risiko rendah. Dua puluh sembilan anak yang mendapat regimen terapi risiko tinggi, 19 anak memenuhi kriteria penelitian, telah menyelesaikan terapi fase induksi, konsolidasi dan reinduksi dengan masing-masing total dosis Daunorubisin $120 \mathrm{mg} / \mathrm{m} 2$, masuk dalam kelompok studi. Empat puluh tiga anak dengan regimen terapi risiko rendah (tanpa Daunorubisin), diambil 21 anak sebagai kelompok kontrol LLA. Kelompok kontrol sehat diambil dari anak yang diperiksa ekokardiografi dengan hasil normal sejumlah 18 anak. Semua anak kelompok studi maupun kelompok kontrol tidak ada yang menunjukkan gejala klinis gagal jantung.

Tabel 1 menunjukkan kemaknaan subyek pada kelompok studi dan kontrol LLA laki-laki lebih banyak dari pada wanita sedangkan pada kelompok kontrol sehat sebaliknya, namun keadaan tersebut secara statistik tidak berbeda bermakna. Rerata umur, berat badan dan luas permukaan tubuh pada ketiga kelompok dalam penelitian ini sebanding. Rerata lama follow up pada kelompok studi 11,84 (SB 11,47) bulan. Status gizi pada kelompok kontrol sehat sebagian besar gizi baik, tidak ada yang gizi buruk. Denyut jantung rerata pada kelompok studi dan kelompok kontrol berkisar 91 sampai 94x/ menit.

\section{Fungsi diastolik ventrikel kiri}

Dua belas dari 19 pasien kelompok studi mengalami gangguan fungsi diastolik ventrikel kiri sedangkan pada kelompok kontrol LLA dan kontrol sehat masingmasing 5/21 dan 0/18 pasien, dan secara statistik ditemukan perbedaan bermakna (Tabel 2).

Pada Tabel 3 tertera rerata gelombang E dan A pada kelompok studi dan kontrol tidak berbeda bermakna. Rerata rasio E/A pada kelompok studi lebih kecil dibandingkan kedua kelompok kontrol, secara statistik terdapat perbedaan bermakna dengan $\mathrm{p}=0,02$. 
Sari Pediatri, Vol. 7, No. 3, Desember 2005

Tabel 1. Karakteristik subyek penelitian

\begin{tabular}{lccc}
\hline Parameter & $\begin{array}{c}\text { Kelompok } \\
\text { studi }\end{array}$ & $\begin{array}{c}\text { Kelompok } \\
\text { kontrol LLA }\end{array}$ & $\begin{array}{c}\text { Kelompok } \\
\text { kontrol sehat }\end{array}$ \\
\hline $\begin{array}{l}\text { 1. Kelamin } \\
\text { - Laki-laki }\end{array}$ & 13 & 12 & 7 \\
$\quad$ - Wanita & 6 & 9 & 11 \\
2. Umur (tahun) & $9,47(3,34)$ & $7,94(1,55)$ & $6,08(1,62)$ \\
Rerata (SB) & $21,91(6,47)$ & $22,66(4,66)$ & $19,18(4,59)$ \\
3. Berat badan (kg) & & & \\
Rerata (SB) & $0,87(0,21)$ & $0,77(0,14)$ & $0,66(0,12)$ \\
4. Luas Permukaan & & & \\
Tubuh (m2) & & 7 & 5 \\
Rerata (SB) & 8 & 9 & 0 \\
5. Status Gizi & 7 & 5 & $93,9(10,2)$ \\
- baik & 4 & $91,3(8,3)$ & \\
- kurang & & & \\
- buruk & $94,1(7,6)$ & & \\
6. Denyut jantung & & & \\
x/menit & & & \\
Rerata (SB) & & & \\
\hline
\end{tabular}

Tabel 2. Gangguan fungsi diastolik ventrikel kiri kelompok studi dan kelompok kontrol

\begin{tabular}{lcccc}
\hline Fungsi Diastolik Ventrikel kiri & $\begin{array}{c}\text { Kelompok } \\
\text { studi }\end{array}$ & $\begin{array}{c}\text { Kelompok } \\
\text { kontrol LLA }\end{array}$ & $\begin{array}{c}\text { Kelompok } \\
\text { kontrol sehat }\end{array}$ & $\mathrm{p}$ \\
\hline Normal & 7 & 16 & 18 & 0,001 \\
Terganggu & 12 & 5 & 0 & \\
\hline
\end{tabular}

Tabel 3. Perbandingan rerata fungsi diastolik ventrikel kiri kelompok studi dan kelompok kontrol

\begin{tabular}{lcccc}
\hline Fungsi Diastolik Ventrikel kiri & $\begin{array}{c}\text { Kelompok } \\
\text { studi }\end{array}$ & $\begin{array}{c}\text { Kelompok } \\
\text { kontrol LLA }\end{array}$ & $\begin{array}{c}\text { Kelompok } \\
\text { kontrol sehat }\end{array}$ & p \\
\hline Gelombang E* & $1,01(0,15)$ & $1,02(0,20)$ & $1,02(0,27)$ & 0,97 \\
Gelombang A* & $0,71(0,15)$ & $0,66(0,15)$ & $0,58(0,18)$ & 0,06 \\
Rasio E/A* & $1,43(0,44)$ & $1,61(0,42)$ & $1,80(0,32)$ & 0,02 \\
\hline
\end{tabular}

*Rerata $(\mathrm{SB})$

\section{Fungsi sistolik ventrikel kiri}

Didapatkan 1/19 pasien pada kelompok studi yang mengalami gangguan fungsi sistolik ventrikel kiri, tidak didapatkan pada kelompok kontrol, secara statistik tidak berbeda bermakna (Tabel 4).

Rerata fraksi ejeksi dan fraksi pemendekan pada kelompok studi kontrol masih dalam batas normal, secara statistik tidak berbeda bermakna (Tabel 5).

\section{Dimensi ventrikel kiri}

Tabel 6 menunjukkan dimensi ventrikel kiri kelompok studi dan kontrol. Terdapat dilatasi ventrikel kiri 4/19 dan 5/21 pada kelompok studi dan kontrol LLA, sedangkan pada kelompok kontrol sehat tidak ada perubahan dimensi ventrikel kiri, secara statistik tidak ditemukan perbedaan bermakna. 
Tabel 4. Fungsi sistolik ventrikel kiri

\begin{tabular}{lcccc}
\hline Fungsi Diastolik Ventrikel kiri & $\begin{array}{c}\text { Kelompok } \\
\text { studi } \\
(\mathrm{n})\end{array}$ & $\begin{array}{c}\text { Kelompok } \\
\text { kontrol LLA } \\
(\mathrm{n})\end{array}$ & $\begin{array}{c}\text { Kelompok } \\
\text { kontrol sehat } \\
(\mathrm{n})\end{array}$ & $\mathrm{p}$ \\
\hline Normal & 18 & 21 & 18 & 0,47 \\
Terganggu & 1 & 0 & 0 & \\
\hline
\end{tabular}

Tabel 5. Perbandingan rerata fungsi sistolik ventrikel kiri Kelompok studi dan kelompok kontrol

\begin{tabular}{lcccc}
\hline $\begin{array}{l}\text { Fungsi } \\
\text { Sistolik Vki }\end{array}$ & $\begin{array}{c}\text { Kelompok } \\
\text { studi }\end{array}$ & $\begin{array}{c}\text { Kelompok } \\
\text { kontrol LLA }\end{array}$ & $\begin{array}{c}\text { Kelompok } \\
\text { kontrol sehat }\end{array}$ & p \\
\hline Fraksi ejeksi $(\%)^{*}$ & $77,80(7,76)$ & $78,38(6,08)$ & $75,01(7,67)$ & 0,37 \\
Fraksi & $40,20(7,50)$ & $39,82(6,91)$ & $0,58(0,18)$ & 0,06 \\
\hline Pemendekan $(\%)^{*}$ & & & &
\end{tabular}

${ }^{*}$ Rerata (SB)

Tabel 6. Dilatasi ventrikel kiri kelompok studi dan kelompok kontrol LLA

\begin{tabular}{lcccc}
\hline Dimensi VKi & $\begin{array}{c}\text { Kelompok } \\
\text { studi } \\
(\mathrm{n})\end{array}$ & $\begin{array}{c}\text { Kelompok } \\
\text { kontrol LLA } \\
(\mathrm{n})\end{array}$ & $\begin{array}{c}\text { Kelompok } \\
\text { kontrol sehat } \\
(\mathrm{n})\end{array}$ & $\mathrm{p}$ \\
\hline Dilatasi & 4 & 5 & 0 & 0,08 \\
Normal & 15 & 16 & 18 & \\
\hline
\end{tabular}

Rerata dimensi ventrikel kiri saat diastolik maupun saat sistolik secara statistik tidak berbeda bermakna antara kelompok studi dan kontrol, p=0,08. Ketebalan septum dan dinding posterior ventrikel kiri lebih tipis pada kelompok kontrol LLA dibanding kelompok studi dan kelompok kontrol sehat (Tabel 7).

\section{Status Gizi}

Status gizi pada kelompok studi dan kontrol secara statistik tidak berbeda bermakna (Tabel 8). Pada kelompok kontrol sehat tidak terdapat penderita dengan gizi buruk.
Tidak terdapat perbedaan status gizi kelompok studi dan kontrol LLA dalam hubungan dengan adanya gangguan fungsi diastolik ventrikel kiri (Tabel 9).

\section{Pembahasan}

Penelitian ini adalah penelitian analitik observasional belah lintang (cross sectional). Keterbatasan penelitian ini antara lain lebih banyak menjaring subyek yang mempunyai masa sakit yang panjang daripada mereka yang mempunyai masa sakit yang pendek. ${ }^{11}$ Pemilihan sampel penelitian tidak dapat dilakukan secara random

Tabel 7. Perbandingan rerata dimensi ventrikel kiri kelompok studi dan kelompok kontrol

\begin{tabular}{lcccc}
\hline Dimensi ventrikel kiri & $\begin{array}{c}\text { Kelompok } \\
\text { studi }\end{array}$ & $\begin{array}{c}\text { Kelompok } \\
\text { kontrol LLA }\end{array}$ & $\begin{array}{c}\text { Kelompok } \\
\text { kontrol sehat }\end{array}$ & $\mathrm{p}$ \\
\hline LVDd $(\mathrm{mm})^{*}$ & $34,77(5,21)$ & $34,33(4,00)$ & $33,20(3,96)$ & 0,543 \\
LVDs $(\mathrm{mm})^{*}$ & $29,85(3,42)$ & $20,28(2,39)$ & $20,93(3,21)$ & 0,762 \\
IVSd $(\mathrm{mm})^{*}$ & $6,42(1,30)$ & $5,81(1,16)$ & $6,73(0,88)$ & 0,043 \\
IVSs $(\mathrm{mm})^{*}$ & $9,68(1,57)$ & $8,66(1,64)$ & $9,35(1,49)$ & 0,119 \\
LVPWd $(\mathrm{mm})^{*}$ & $6,16(1,07)$ & $5,56(1,19)$ & $6,51(1,07)$ & 0,032 \\
LVPWs $(\mathrm{mm})^{*}$ & $11,34(1,61)$ & $10,05(1,70)$ & $9,60(0,95)$ & 0,020 \\
\hline
\end{tabular}

* Rerata (SB) 
Sari Pediatri, Vol. 7, No. 3, Desember 2005

Tabel 8. Status gizi kelompok studi dan kelompok kontrol

\begin{tabular}{lcccc}
\hline Status Gizi & $\begin{array}{c}\text { Kelompok } \\
\text { studi } \\
(\mathrm{n})\end{array}$ & $\begin{array}{c}\text { Kelompok } \\
\text { kontrol LLA } \\
(\mathrm{n})\end{array}$ & $\begin{array}{c}\text { Kelompok } \\
\text { kontrol Sehat } \\
(\mathrm{n})\end{array}$ & $\mathrm{p}$ \\
\hline Baik & 8 & 7 & 13 & 0,09 \\
Kurang & 7 & 9 & 5 & \\
Buruk & 4 & 5 & 0 & \\
\hline
\end{tabular}

Tabel 9. Hubungan status gizi dan gangguan fungsi diastolik ventrikel kiri kelompok studi dan kelompok kontrol LLA

\begin{tabular}{lcccc}
\hline Fungsi Diastolik Ventrikel kiri & $\begin{array}{c}\text { Status gizi } \\
\text { Buik } \\
(\mathrm{n})\end{array}$ & $\begin{array}{c}\text { Buruk } \\
(\mathrm{n})\end{array}$ & $\mathrm{p}$ \\
\hline $\begin{array}{l}\text { Kelompok Studi } \\
\quad \text { normal } \\
\quad \text { terganggu }\end{array}$ & 2 & 4 & 1 & 0,375 \\
$\begin{array}{l}\text { Kelompok Kontrol LLA } \\
\text { normal }\end{array}$ & 6 & 3 & 3 & \\
terganggu & 5 & 3 & 8 & 0,447 \\
\hline
\end{tabular}

karena jumlah kasus yang terbatas. Kasus yang masuk dalam penelitian ini adalah kasus yang diterapi dengan regimen Wijaya Kusuma 2000 baik kasus risiko standar maupun kasus risiko tinggi. Kasus risiko tinggi mendapat terapi daunorubisin dengan dosis total 120 $\mathrm{mg} / \mathrm{m}^{2}$ luas permukaan tubuh. Kasus-kasus dengan dosis daunorubisin $<120$ dan $>120 \mathrm{mg} / \mathrm{m} 2$ tidak masuk dalam penelitian. Di RSU Dr Soetomo Surabaya angka drop out pengobatan pasien LLA $42,8 \%$ dan angka kematian 15\%, sehingga total kasus risiko tinggi jumlahnya tidak banyak. Pemeriksaan ekokardiografi pada penelitian ini dilakukan oleh peneliti sendiri tanpa melibatkan peneliti lain, sehingga subyektivitas hasil pemeriksaan dapat terjadi. Hal ini sedikit banyak akan mempengaruhi hasil penelitian.

Pada anamnesis dan pemeriksaan fisis anak kelompok studi maupun kelompok kontrol tidak didapatkan keluhan maupun tanda adanya gagal jantung kongestif. Marchandise dkk mendapatkan 2-20\% pasien memberikan manifestasi klinis gagal jantung. ${ }^{4,8}$ Untuk timbulnya gejala dan tanda gagal jantung perlu waktu yang panjang dan dosis kumulatif yang tinggi ${ }^{12-14}$ Insidens gagal jantung kongestif pada dosis kumulatif $<400,550,700 \mathrm{mg} / \mathrm{m} 2$ berturt-turut $0,14 \%, 7 \%$ dan $18 \% .{ }^{4}$ Faktor risiko terjadinya gagal jantung kongestif pada pasien pasca terapi daunorubisin antara lain radioterapi mediastinum, pemberian terapi bersamaan dengan siklofosfamid, umur terlalu tua atau terlalu muda, adanya hipertensi, dan penyakit jantung lainnya. ${ }^{4}$

Karakteristik kelompok studi dan kelompok kontrol pada penelitian ini sebanding dalam variabel jenis kelamin, umur, berat badan dan luas permukaan tubuh serta denyut jantung. Keadaan ini penting agar variabel yang diteliti dapat dibandingkan. Pengelompokan pasien pada penelitian ini berdasarkan regimen terapi kelompok risiko tinggi (kelompok studi) dan kelompok risiko standar (kelompok kontrol LLA), serta kelompok kontrol sehat. Regimen terapi untuk kelompok risiko tinggi terdapat daunorubisin yang telah diketahui mempunyai efek kardiotoksik yang tergantung pada dosis kumulatif. Sedangkan kelompok risiko standar tidak mendapat terapi daunorubisin. Pemberian daunorubisin pada kelompok risiko tinggi sesuai protokol Wijaya Kusuma LLA pada anak-2000. ${ }^{15}$ Pemberian sebanyak 4 kali yaitu 1 kali pada fase induksi dan 3 kali pada fase reinduksi dengan dosis masing-masing $30 \mathrm{mg} / \mathrm{m} 2$ dan jarak antara pemberian obat masing-masing 2 minggu sehingga dosis kumulatif $=120 \mathrm{mg} / \mathrm{m}^{2}$.

Beberapa penelitian menunjukkan bahwa gangguan awal fungsi jantung adalah gangguan fungsi diastolik. Pola gangguan fungsi diastolik ventrikel dapat berupa pola penurunan relaksasi yaitu puncak E menurun, puncak A meningkat dan rasio E/A menurun, maupun 
pola restriktif yaitu puncak E meningkat, puncak A menurun dan rasio E/A meningkat. Pola penurunan relaksasi terdapat pada kardiomiopati hipertrofi maupun kardiomiopati dilatasi, hipertrofi ventrikel kiri karena berbagai sebab, penyakit jantung iskemik, preload yang menurun seperti pada dehidrasi, afterload yang meningkat sepertipada keadaan infus dan vasokonstriksi. Pola restriktif terdapat pada kardiomiopati restriktif dan pada gagal jantung karena berbagai macam sebab. ${ }^{10}$ Abnormalitas fungsi diastolik biasanya nonspesifik, tidak memberikan informasi diagnostik yang berdiri sendiri. ${ }^{10}$

Pada penelitian ini fungsi diastolik ventrikel kiri yang diukur puncak gelombang E, A dan rasio E/A. Sedangkan variabel lain seperti IVRT, AT,DT tidak diukur, karena pertimbangan praktis. Secara statistik tidak terdapat perbedaan bermakna nilai rerata puncak E dan A pada penelitian ini. Sedangkan rasio E/A pada kelompok studi, kontrol LLA dan kontrol sehat berturut-turut $1,43(0,44), 1,61(0,42)$, dan $1,80(0,32)$, secara statistik terdapat perbedaan bermakna,rasio E/A pada kelompok studi menurun. Namun apabila dilihat nilai masing-masing individu dan dibandingkan dengan nilai normal menurut berat badan dan luas permukaan tubuh didapatkan gangguan fungsi diastolik pada kelompok studi yaitu 12 dari 19 anak, pada kelompok kontrol LLA 5 dari 21 anak sedangkan pada kelompok kontrol sehat tidak ada gangguan fungsi diastolik, yang secara statistik berbeda bermakna.

Gangguan fungsi diastolik pada penelitian ini menunjukkan pola penurunan relaksasi yang tampak pada penurunan rasio E/A yang sesuai dengan gambaran pada kardiomiopati dilatasi. Pada kelompok kontrol LLA juga sudah terdapat gangguan fungsi diastolik ventrikel kiri. Disamping daunorubisin ada faktor lain yang mempengaruhi fungsi diastolik ventrikel kiri pada anak dengan LLA, mungkin faktor penyakitnya sendiri dan obat-obat lain yang diberikan. Hasil yang sama didapatkan oleh Larussi D dan kawan-kawan dari penelitian pada 101 anak pasca terapi daunorubisin minimal 12 bulan. ${ }^{16} \mathrm{Hal}$ sebaliknya didapatkan oleh Bossi dan kawan-kawan, dari penelitian pada 117 anak pasca terapi daunorubisin median usia 7 tahun,terdapat gangguan fungsi sistolik tetapi tidak terdapat gangguan fungsi sistolik. ${ }^{17}$ Bullock FA dan kawan-kawan, ${ }^{5}$ mendapatkan gangguan fungsi diastolik mulai pada dosis $>100 \mathrm{mg}$ $/ \mathrm{m}^{2}$ pasca terapi minimal 6 bulan. Cottin $\mathrm{dkk}^{9}$ tahun 1995 mendapatkan adanya gangguan fungsi diastolik ventrikel kiri pada 12 dari 35 anak dengan terapi daunorubisin dosis antara 75 sampai $550 \mathrm{mg} / \mathrm{m} 2$ pada pemeriksaan fungsi jantung dengan radionuklid. Gangguan fungsi diastolik dapat berupa gelombang $\mathrm{E}$ yang meningkat dan gelombang A yang menurun (pola restriktif) pada dosis antrasiklin yang tinggi, pada antrasiklin dosis rendah dan fungsi sistolik yang masih baik polanya gelombang E normal atau meningkat dan gelombang A yang meningkat. ${ }^{5}$

Penelitian Leandro $\mathrm{J} \mathrm{dkk}^{18}$ mengenai gangguan fungsi sistolik ventrikel kiri telah banyak dilakukan, semuanya pada follow up jangka panjang. ${ }^{18}$ Keadaan ini diduga akibat dari gangguan potensi tumbuh dan berkurangnya massa otot jantung. Terapi daunorubisin menyebabkan gangguan fungsi ventrikel kiri karena efek toksik pada sel otot jantung. Kardiomiopati yang terjadi biasanya berat, disfungsi ventrikel kiri yang ireversibel sebelum tampak tanda gagal jantung. ${ }^{19} \mathrm{Pada}$ penelitian ini tidak didapatkan gangguan fungsi sistolik ventrikel kiri yang secara statistik bermakna pada kelompok studi dibandingkan kelompok kontrol. Keadaan ini berhubungan dengan dosis daunorubisin yang masih relatif rendah dan follow up yang masih pendek yaitu rerata 16 bulan. Lee BH dkk (1987) mendapatkan hal yang sama,fungsi diastolik ventrikel kiri terganggu, tetapi fungsi sistolik tidak terganggu pada pasien dengan dosis kumulatif $<200 \mathrm{mg} / \mathrm{m} 2$. $^{7}$ Bullock FA dkk mendapatkan gangguan fungsi sistolik ventrikel kiri berupa penurunan $\mathrm{FP}<30 \%$ walaupun pada dosis $<100 \mathrm{mg} / \mathrm{m}^{2}$. Pada kelompok studi penelitian ini terdapat 1 orang anak dengan gangguan fungsi sistolik ventrikel kiri. Keadaan ini mungkin berkaitan denga faktor lain, seperti adanya adanya invasi sel LLA ke dalam miokardium atau ke dalam rongga perikardium. Keadaan lain yang dapat memberikan gejala gangguan fungsi sistolik ventrikel kiri antara lain sepsis, ${ }^{20}$ anemia dengan kadar hemoglobin $<6 \mathrm{~g} / \mathrm{dl},{ }^{21}$ kardiomiopati dilatasi idiopatik. Pemeriksaan fungsi sistolik ventrikel kiri dalam keadaan istirahat dapat menunjukkan hasil yang normal walaupun sebenarnya sudah ada kerusakan pada miokard karena daunorubisin. ${ }^{22}$ Pemeriksaan stress ekokardiografi mungkin dapat dipertimbangkan pada kasus-kasus kardiomiopati subklinis. ${ }^{15}$

Dimensi ventrikel kiri pada saat diastolik maupun pada saat sistolik secara statistik tidak berbeda bermakna setelah pemberian dounorubisin dibandingkan kelompok kontrol, belum terjadi kondisi kardiomiopati yang berhubungan dengan dosis kumulatif yang tinggi dan waktu lama untuk 
timbulnya manifestasi klinis. Bullock FA dkk mendapatkan penipisan dinding posterior ventrikel kiri walaupun setelah pemberian daunorubisin dosis rendah. ${ }^{5}$ Pada pengukuran ketebalan septum dan dinding posterior ventrikel kiri didapatkan lebih tipis pada kelompok kontrol LLA dibandingkan kelompok studi. Keadaan ini berlawanan dengan temuan pada penelitian sebelumnya, mungkin disebabkan oleh faktor lain selain daunorubisin seperti pengaruh obatobat lain yang diberikan. Dalam follow up jangka panjang pada penelitian-penelitian terdahulu didapatkan septum dan dinding posterior ventrikel kiri menipis akibat kerusakan miokardium akibat pemberian obat golongan antrasiklin.

Tidak terdapat perbedaan status gizi antara kelompok studi dan kelompok kontrol. Status gizi kurang dan buruk paling banyak ditemukan pada kedua kelompok dibandingkan status gizi baik. Kondisi ini disebabkan oleh penyakit keganasan itu sendiri maupun karena masukan makanan yang kurang. Pada kelompok studi tidak didapatkan perbedaan yang bermakna antara gizi baik, gizi kurang maupun gizi buruk dalam hal timbulnya gangguan fungsi diastolik. Obama dkk(1983) mendapatkan anak-anak dengan malnutrisi lebih banyak mengalami kardiotoksisitas pada pemberian antrasiklin dosis kumulatif antara 135$540 \mathrm{mg} / \mathrm{m}^{2}$. Penilaian adanya kardiotoksisitas pada penelitian tersebut berdasarkan gambaran elektrokardiografi dan gambaran klinis gagal jantung, penilaian dengan ekokardiografi tidak dilakukan. ${ }^{15}$

\section{Kesimpulan}

Pada anak dengan penyakit leukemia limpoblastik akut pasca terapi daunorubisin dosis kumulatif $120 \mathrm{mg} / \mathrm{m} 2$ dapat mengalami gangguan fungsi diastolik ventrikel kiri, sedangkan fungsi sistolik tidak terganggu. Dimensi ventrikel kiri tidak mengalami perubahan. Tidak terdapat perbedaan status gizi pada anak dengan fungsi diastolik terganggu dibanding fungsi diastolik normal. Disarankan pemantauan efek kardiotoksisitas daunorubisin dengan pemeriksaan ekokardiografi sebelum dan sesudah pemberi daunorubisin perlu ditingkatkan. Pasien follow up jangka panjang perlu pencatatan lebih baik agar data tidak hilang dan bisa dievaluasi. Perlu penelitian lebih lanjut untuk evaluasi pada kasus dengan dosis daunorubisin dosis lebih tinggi dan follow up jangka waktu lebih panjang.

\section{Daftar Pustaka}

1. Gatot Djajadiman. Masalah penyakit keganasan pada anak dan pendekatan diagnostiknya. Dalam : Wahidayat I, Gatot D, Mangunatmadja I, penyunting. Perkembangan mutakhir penyakit hematologi onkologi anak. Naskah lengkap Pendidikan Tambahan Berkala Ilmu Kesehatan Anak XXIV FKUI; 19916 - 7 September; Jakarta: Bagian Ilmu Kesehatan Anak FKUI, 1991. h. 1-8

2. Moeslichan Mz S. Prinsip pengobatan penyakit keganasan pada anak. Dalam : Wahidayat I, Gatot D, Mangunatmadja I, penyunting. Perkembangan mutakhir penyakit hematologi onkologi anak. Naskah lengkap Pendidikan Tambahan Berkala Ilmu Kesehatan Anak XXIV FKUI, 19916 - 7 September, Jakarta: Bagian Ilmu Kesehatan Anak FKUI, 1991. h. 15-26

3. Abdulsalam M. Efek samping sitostatika dan penanggulangannya. Dalam: Wahidayat I, Gatot D, Mangunatmadja I, penyunting. Perkembangan mutakhir penyakit hematologi onkologi anak. Naskah lengkap Pendidikan Tambahan Berkala Ilmu Kesehatan Anak XXIV FKUI, 19916 - 7 September, Jakarta: Bagian Ilmu Kesehatan Anak FKUI, 1991. h. 31-42

4. Von Hoff DD, Layard MW, Basa P, dkk. Risk factors for doxorubicin-induced congestive heart failure. Ann Intern Med 1979;91:710-7.

5. Bulock FA, Mott GM, Oakhill A, Martin EP. Left ventricular diastolic function after anthracycline chemotherapy in childhood: relation with systolic function, symptoms, and pathophysiology. Br Heart J 1995; 73:340-50.

6. Rhoden W, Hasleton P, Brooks N. Anthracycline and the heart. Br Heart J 1993; 70:499-502.

7. Lee BH, Goodenday LS, Muswick GJ. Alteration in left ventricular diastolic function with doxorubicin therapy. J Am Coll Cardiol 1987; 9:184-8.

8. Marchandise B, Schroeder E, Bosly A. Early detection of doxorubicin cardiotoxicity: interest of doppler echocardiographic analysis of left ventricular filling dynamics. Am Heart J 1989; 118:92-8.

9. Cottin Y, Touzery C, Coudert B. Impairment of diastolic function during short-term anthracycline chemotherapy. Br Heart J 1995; 73:61-4.

10. Park MK. Pediatric Cardiology For Practitioners. Edisi ketiga. St Louis: Mosby, 1996. h. 67-82.

11. Sastroasmoro S, Ismael S. Dasar-Dasar Metodologi Penelitian Klinis. Edisi 1. Jakarta Binarupa Aksara, 1995. h. 66-77. 
12. Steinherz LJ, Steinherz PG, Tan TC. Cardiac toxocity 4 to 20 years after completing anthracycline therapy. JAMA 1991;266:1672-7.

13. Elbl, L., H. Hrstkova. "The late consequences of anthracycline treatment on left ventricular function after treatment for childhood cancer." Eur J Pediatr 2003;162: 690-6

14. Kremer, L. C., H. J. van der Pal. "Frequency and risk factors of subclinical cardiotoxicity after anthracycline therapy in children: a systematic review.” Ann Oncol 2002;13:819-29

15. Protokol Wijaya Kusuma Lekemia Limfoblastik Akut pada anak-2000(WK-ALL-2000) Penelitian multisenter Indonesia, Bagian Ilmu Kesehatan Anak, RSUP dr Sardjito/Fakultas Kedokteran Universitas Gajah Mada, Yogyakarta, 2000.

16. Larussi D, Galderisi M, Ratti G, Tedesco MA, Indolfi P,Casale F, dkk. Left Ventricular Systolic and Diastolic Function after Anthracycline Chemotherapy in Childhood. Clin.Cardiol 2001;24:663-9.

17. Bossi, G., L. Lanzarini. "Echocardiographic evaluation of patients cured of childhood cancer: a single center study of 117 subjects who received anthracyclines. Med Pediatr Oncol 2001;36:593-600

18. Leandro J, Dyck J, Poppe D, Share R. Cardiac dysfunction late after cardiotoxic therapy for childhood cancer. Am J Cardiol 1994;74:1152-6.

19. AHA/ALL Task ForceReport. Guidelines For Cardiac Radionuclide Imaging. Circulation 1995;91:1278.

20. Ferdman B, Jureidini SB, Gale G, Mink R. Severe Left Ventricular Dysfunction and Arrhythmias as complication of gram positive sepsis: rapid recovery in children. Pediatr Cardiol 1998;19:482-6

21. Hayashi R, Ogawa S, watanabe Z, Yamamoto M. Cardiovascular Function after iron therapy in patients with iron deficiency anemia. Pediatr Int 1999;41:13-7

22. Yeung ST, Yoong C, Spink J, Galbraith A, Smith PJ. Functional myocardial impairment in children treated with anthracycline for cancer. Lancet 1991;337:816-8.

23. Obama M, Cangir A, Van Eys. Nutritional status and anthracycline cardiotoxicity in children. South Med J 1983;76:577-8. 